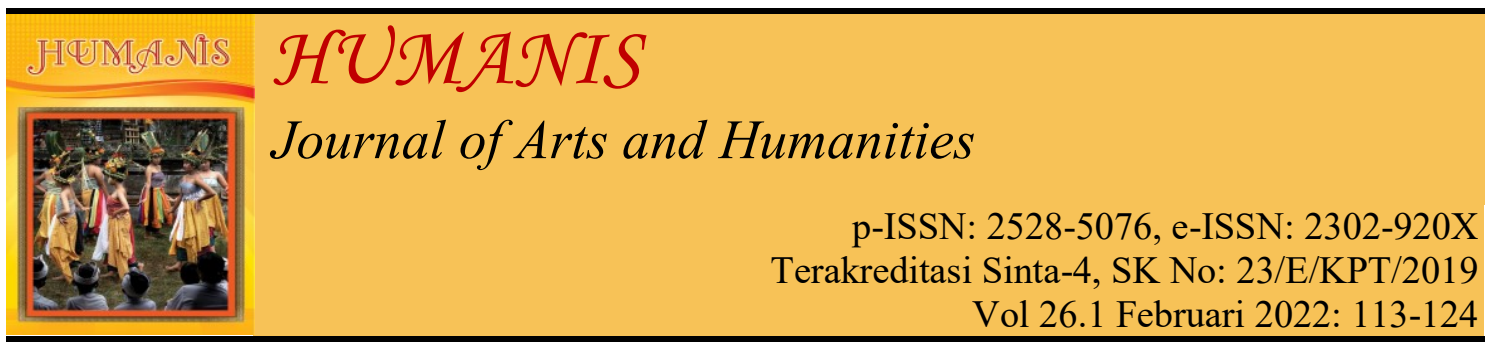

\title{
Sistem Penguburan di Situs Doro Mpana, Dompu, Nusa Tenggara Barat
}

\author{
Lila Jamilah, I Wayan Srijaya, Rochtri Agung Bawono \\ Universitas Udayana, Denpasar, Bali. \\ Email korespondensi: 1ilajamilah902@gmail.com, srijaya59@yahoo.com, \\ agung bawono@unud.ac.id
}

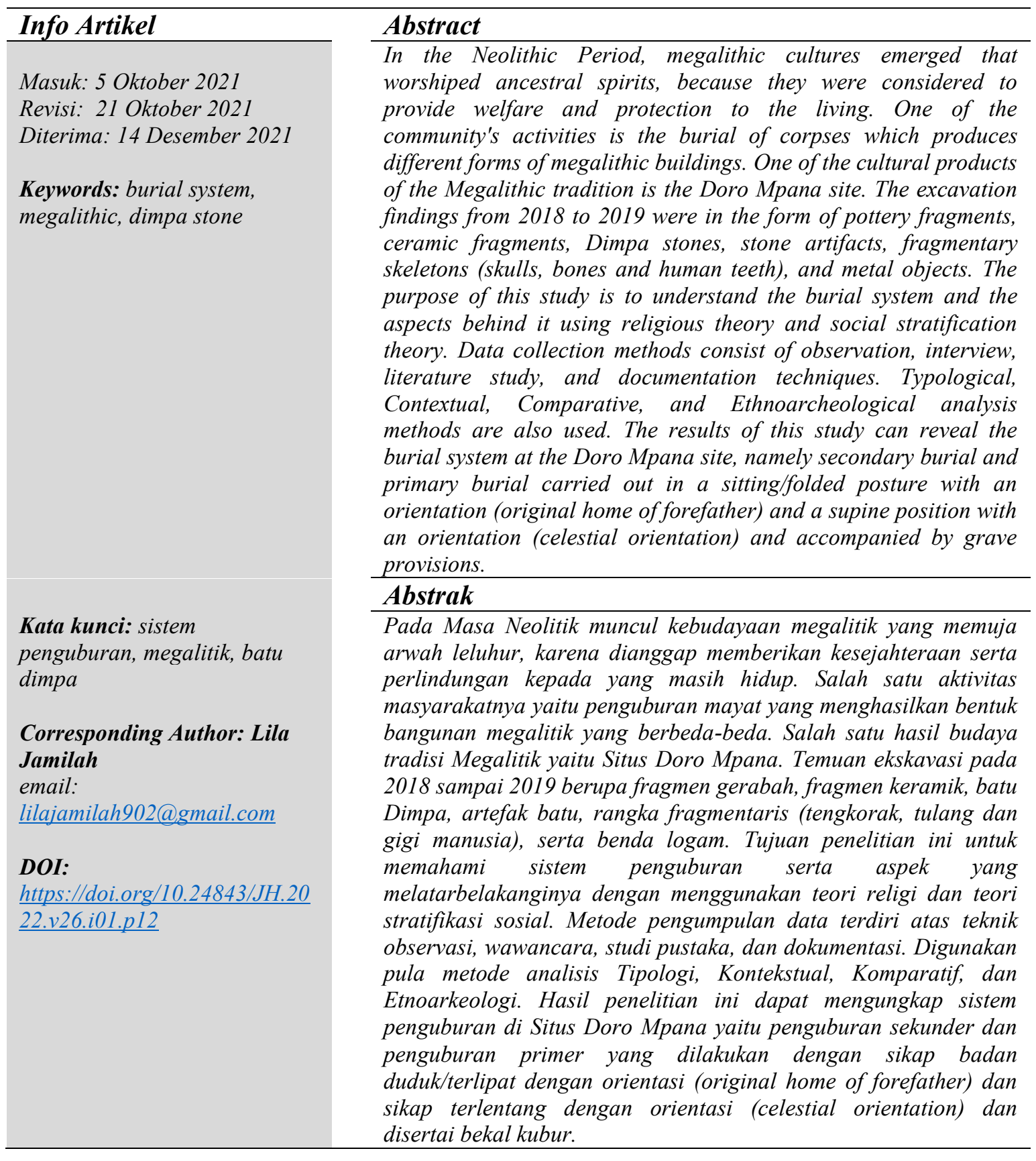




\section{PENDAHULUAN}

Manusia tidak dapat lepas dari dua peristiwa penting dalam kehidupannya yaitu kelahiran dan kematian. Kematian adalah akhir dari kehidupan. Penguburan merupakan salah satu rangkaian dalam ritual kematian yang merupakan bentuk tradisi terhadap keberadaan arwah nenek moyang.

Bukti tertua sistem penguburan telah ada kurang lebih 500.000 tahun yang lalu berdasarkan temuan ekskavasi fosil Homo Neandhertal di Eropa. Data tersebut memberikan gambaran tentang cara penguburan, dan penyertaan bendabenda bekal kuburnya. Situs Gua Lawa (Sampung) dianggap mewakili data tertua adanya kegiatan penguburan di Indonesia. Data tersebut merupakan penemuan rangka yang dikuburkan dalam posisi terlipat (flexed position), dengan tangan di bawah dagu atau menutup mata yang merupakan cara penguburan dari Zaman Mesolitik (Heekeren, 1972: 94; Widianto, 1990: 15).

Di Indonesia temuan kubur di guagua hunian yang berkembang pada Masa Mesolitik dan Neolitik (bercocok tanam), ketika manusia mulai mengenal adanya religi dan ketidaktahuan manusia mengenai misteri kematian. Pada Masa Neolitik muncul tradisi budaya megalitik atau kebudayaan pemujaan terhadap leluhur (Soejono dkk., 1993: 16-17). Pendukung tradisi ini beranggapan bahwa setiap orang yang meninggal dunia dapat hidup kembali di alam lain dan masih memiliki hubungan yang erat karena dapat memberikan kesejahteraan serta perlindungan. Salah satu aktivitas masyarakat pendukung tradisi megalitik yaitu cara-cara perawatan dan penguburan mayat yang banyak menghasilkan bentuk bangunan megalitik yang berbeda-beda. Hal ini menggambarkan karakteristik kebudayaan dari setiap masyarakat pendukungnya.
Salah satu hasil budaya tradisi Megalitik yaitu Situs Doro Mpana. Situs ini pertama kali diteliti pada 2018 untuk mencari jejak pemukiman Masa Awal Kesultanan Dompu berdasarkan adanya temuan fragmen gerabah, fragmen keramik, batu Dimpa, benda logam dan rangka manusia. Temuan fragmen keramik asing membuktikan bahwa masyarakat pendukung Situs Doro Mpana telah mengadakan hubungan dengan dunia luar (Juliawati dkk, 2018: 4).

Penelitian tahap kedua di Situs Doro Mpana mencoba mengungkap kronologi pemanfaatan Situs Doro Mpana dan kondisi lingkungan masa lalu serta perubahannya. Berdasarkan hasil analisis radio carbon dating $\mathrm{C} 14$ terhadap sampel arang menunjukkan bahwa pemanfaatan Situs Doro Mpana untuk penguburan terjadi sekitar akhir Abad XIII-XIV Masehi. Masyarakat pendukung Situs Doro Mpana telah memanfaatkan sumber alam di sekitarnya yakni batu diorit yang disebut batu Dimpa oleh masyarakat sekarang sebagai bagian dari ritual penguburan yang dilakukan (Juliawati dkk, 2019: 144-147).

Berdasarkan uraian tersebut, penulis tertarik mengkaji sistem penguburan di Situs Doro Mpana. Tujuan penelitian ini untuk memahami sistem penguburan dan sistem religi yang melatarbelakangi penguburan di Situs Doro Mpana.

\section{METODE DAN TEORI}

Penelitian ini menggunakan empat tahap pengumpulan data penelitian agar mendapatkan jawaban atas permasalah. Studi pustaka dilakukan untuk memperoleh teori dan gambaran mengenai sistem penguburan dan juga mengenai penelitian yang terkait dengan sistem penguburan di Doro Mpana. Observasi dilakukan terhadap data yang telah disimpan di rumah penduduk, dengan melakukan pengukuran, dan 
pengamatan secara langsung terhadap sistem penguburan khususnya batu Dimpa. Wawancara dilakukan untuk memperoleh informasi mengenai proses penemuan rangka manusia dan artefak kubur yang melengkapinya. Dokumentasi dilakukan dengan pemotretan dan perekaman hasil observasi dan wawancara.

Metode analisis dalam penelitian ini terdiri atas metode Analisis tipologi dilakukan dengan menitik beratkan pada ciri-ciri fisik artefak dengan identifikasi bentuk dan ukuran dengan melakukan pengamatan terhadap batu Dimpa, tengkorak, keramik, dan gerabah. Metode Analisis Kontekstual, memperhatikan hubungan artefak dengan artefak, hubungan artefak dengan fitur, dan artefak dengan sumber daya lingkungan. Pengamatan terhadap lingkungan tempat ditemukannya tengkorak, batu Dimpa, serta bekal kubur. Metode Analisis Komparatif, digunakan untuk memperoleh informasi pembanding mengenai sistem penguburan yang memiliki kemiripan pada beberapa aspek seperti konsep batu Dimpa, sikap badan, dan bekal kubur. Metode Analisis Etnoarkeologi, digunakan untuk mengidentifikasi lebih lanjut mengenai hubungan data arkeologi dengan kehidupan kebudayaan yang masih dijumpai saat ini sehingga nantinya dapat diketahui apakah ada suatu persamaan atau perbedaan antara kehidupan manusia masa lalu dengan masa sekarang.

Sebagai landasan kerangka pemikiran dalam penelitian ini ada dua teori yang dikemukakan berkaitan dengan religi menurut W. Robert Smith dalam dengan sistem penguburan yaitu konsep kepercayaan terhadap kehadiran tuhan yang dipuja yang disimbolkan dengan sebuah benda atau tanda serta adanya ritual persembahan (Koentjaraningrat, 1985: 24). Teori stratifikasi sosial menurut Soerjono Soekanto yaitu suatu lapisan masyarakat yang di dalamnya terdapat kelas-kelas sosial dimana di dalam setiap masyarakat dimanapun selalu dan pasti mempunyai sesuatu yang dihargai dan sesuatu yang dihargai di masyarakat itu bisa berupa kekayaan, ilmu pengetahuan, dan keturunan keluarga terhormat (Soekanto, 2012: 197).

\section{HASIL DAN PEMBAHASAN}

$\begin{array}{lrr}\text { a. Konsep } & \begin{array}{c}\text { Kepercayaan } \\ \text { Munculnya }\end{array} & \begin{array}{r}\text { yang } \\ \text { Sistem }\end{array} \\ \begin{array}{l}\text { Melandasi } \\ \text { Penguburan }\end{array} & & \\ \text { Kepercayaan } \quad \text { terhadap } & \text { nenek }\end{array}$ moyang melandasi konsepsi terkait adanya hubungan yang erat antara si mati dan manusia yang masih hidup serta kesejahteraan masyarakat yang ditinggalkan. Salah satu bentuk kepercayaan Animisme-Dinamisme, yaitu masyarakat Dompu percaya dengan Parafu/marafu.

Parafu adalah sebutan masyarakat Dompu pada mahluk sebangsa jin yang mendiami kawasan-kawasan tertentu di daratan, dan mata air (Taufikurrahman, 2018: 26). Supaya terciptanya suatu hubungan yang harmonis serta seimbang antara kedua alam dan agar perjalanan orang yang meninggal ke dunia arwah selalu diberkati, maka diberikan suatu pemakaman yang layak bagi orang yang mati. Manusia menciptakan ritual atau perlakuan khusus terhadap orang yang mati seperti proses penguburan menggunakan wadah, pemberian bekal kubur dan upacara terkait proses penguburan (Prasetyo dkk., 2004: 11).

\section{b. Stratigrafi Temuan Batu Dimpa}

Ekskavasi dimulai dari sudut atau Kuadran Barat Laut yang merupakan permukaan tanah yang paling tinggi. Kotak ini diakhiri sampai spit (11) atau pada kedalaman $115 \mathrm{~cm}$ dari permukaan tanah. Stratigrafi tanah terbagi menjadi empat (lihat gambar 1), lapisan tanah penutup berwarna kelabu dengan tekstur tanah butir pasir halus. Di tengah-tengah 
kotak galian pada spit 5 kedalaman 55 cm nampak batu andesit besar yang diduga sebagai batu Dimpa dengan diameter $66 \mathrm{~cm}$ dan tebal sekitar $12 \mathrm{~cm}$ seperti. Lapisan tanah pada spit ini diduga tanah urungan yang membentuk sebuah fitur penguburan ditandai dengan warna tekstur tanah pasir halus, lempung dan kerikil, berbeda dengan spit sebelumnya.

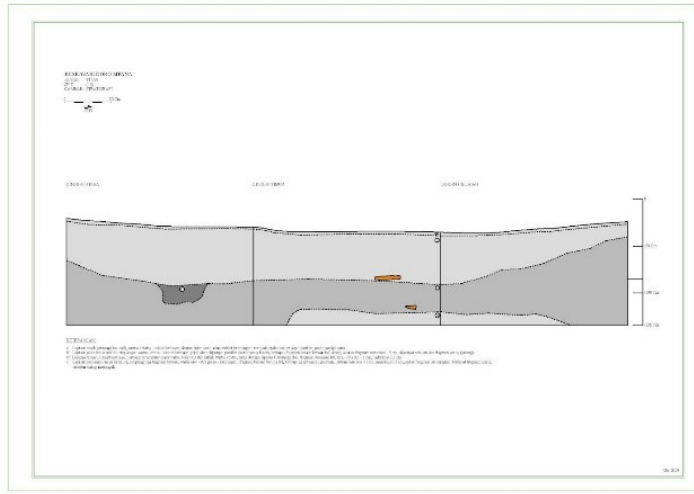

Gambar 1. Stratigrafi dinding utara, timur, dan selatan Kotak TIS20

(Dok: Balar Bali, 2019)

Bagian atas bongkahan batu inilah terdapat temuan fragmen gerabah terkonsentrasi dan temuan arang. Selanjutnya dilakukan penggalian dengan sangat hati-hati untuk mengindari kerusakan-kerusakan terhadap temuan yang ada di bawah batu Dimpa, kemungkinan untuk melihat fitur dan stratigrafinya yang diduga terdapat lubang kubur. Kecurigaan ini muncul karena kondisi tanah pada spit di bawah batu Dimpa memperlihatkan perbedaan jenis tekstur dan warnanya karena adanya aktivitas penguburan. Sehingga muncul dugaan bahwa batu Dimpa yang ditemukan pada kotak ini kemungkinan awalnya berada di permukaan tanah, namun karena adanya gerusan tanah dari atas yang menyebabkannya terkubur. Selain itu pada spit (9) ditemukan gejala atau tulang yang dikubur, namun belum dapat dipastikan temuan tulang tersebut merupakan tulang manusia atau bukan. Namun kondisi tanah di sekitar fitur tersebut menunjukkan adanya gejala fitur kubur.

Kotak ini digali ulang pada 2019 untuk melanjutkan hasil penelitian terdahulu khususnya pada Kuadran Barat Laut dan Timur Laut pada kedalaman 65 $\mathrm{cm}$ dari permukaan tanah. Penggalian Beberapa temuan dari spit sebelumnya tidak diangkat untuk melihat konteks temuan. Penggalian pada spit 12 dilakukan pada kedalaman $125 \mathrm{~cm}$ ditemuan pada spit ini berupa fragmen gerabah, fragmen tulang (belum diangkat), fragmen keramik, fragmen arang, dan batu tatap. Pada Kuadran Barat Laut ditemukan cranium atas (tengkorak) dengan kondisi masih bagus yang keletakannya tepat di bawah batu Dimpa jika dihubungkan dengan konteks temuan. Keberadaan cranium tersebut membuktikan bahwa batu Dimpa digunakan sebagai penanda kubur. Temuan lain berupa batu andesit pada beberapa tempat yang diduga sebagai tatap dan landas untuk pembuatan gerabah dan alat untuk menghaluskan bagian luar gerabah.

\section{c. Penguburan Batu Dimpa}

Batu Dimpa yang berasal dari kata 'batu timpa' merupakan nama yang diberikan masyarakat saat ini untuk batu diorit berbentuk pipih bundar tidak sempurna yang ditemukan di sekitar situs. Hasil survei lingkungan menunjukkan bahwa sumber bahan baku batu Dimpa kemungkinan didapatkan dari singkapan batu diorit yang berada sekitar 100 meter dari lokasi ekskavasi.

Penggunaan batu Dimpa sebagai penanda kubur atau penutup kubur dalam sistem penguburan di Situs Doro Mpana dibuktikan dengan adanya rangka manusia dan berbagai benda yang diduga sebagai bekal. Konsep penguburan yang serupa juga terdapat di Situs kubur duduk dan kubur batu gong di Hu'u ditemukan kerangka manusia berada di bawah batu besar yang sengaja diletakkan di atas 
individu untuk menjaganya dari binatang buas. Kemungkinan sistem penguburan di Situs Doro Mpana memanfaatkan batu Dimpa selain sebagai penanda kubur juga sebagai perlindungan dari binatang buas.

Batu Dimpa yang dapat diamati di pemukiman warga sekitar Situs Doro Mpana sudah banyak yang pecah dan diperkirakan berubah dari bentuk aslinya karena dimanfaatkan masyarakat untuk berbagai hal diantaranya sebagai tatakan kaki depan teras rumah, dan sebagai bahan bangunan. Batu Dimpa yang ditemukan dalam survei lapangan berjumlah 8 . Hasil survei lapangan yang dilakukan oleh penulis terhadap batu Dimpa yang ditemukan di rumah warga berjumlah delapan batu, dan dikategorikan menjadi empat berdasarkan bentuknya yaitu tipe monolith, tipe bulat alami, tipe trapesium, dan tipe segi empat. Ukurannya terbagi menjadi tiga yaitu kecil, sedang, dan besar. Bentuknya monolith dan bulat alami biasanya memiliki ukuran yang lebih kecil atau cenderung sedang, sedangkan untuk tipe segiempat dan trapesium memiliki ukuran yang lebih besar dan bentuk yang lebih rapi. Kemungkinan besar bentuk segiempat dan trapesium mewakili status sosial masyarakat yang tinggi. Perbedaan bentuk dan ukuran pada batu Dimpa ini kemungkinan dipengaruhi oleh status sosial si mati. Hal ini bukan tanpa alasan, melihat tingkat kesulitan untuk memperoleh bahan batu Dimpa dan proses pengerjaan yang membutuhkan waktu dan biaya yang jauh lebih besar.

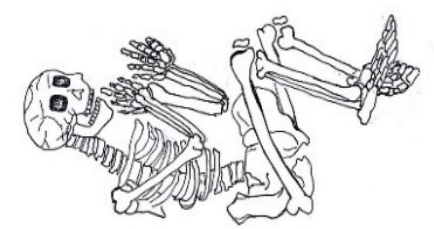

Gambar 5. Ilustrasi rangka dalam posisi duduk di Situs Doro Mpana.

(Dok: Lila Jamilah, 2021)

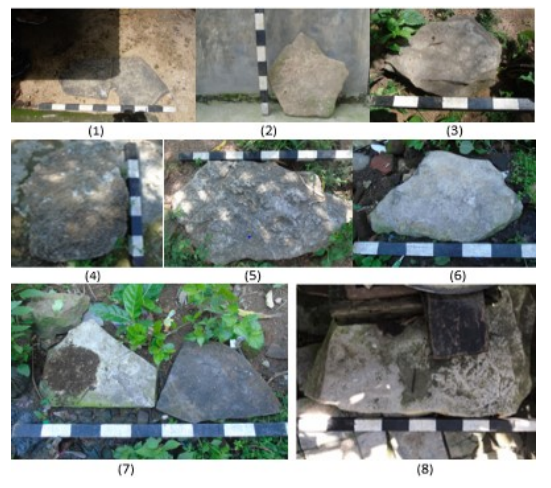

Gambar 2. Batu Dimpa di rumah warga

(Dok: Lila Jamilah, 2021)

Perbedaan ukuran batu Dimpa menunjukkan adanya perbedaan status sosial mayat yang dikubur. Kemungkinan batu Dimpa yang berukuran besar diperuntukkan kepada tokoh penting seperti kepala suku dalam masyarakat kala itu. Hal ini didasarkan pada stratifikasi sosial masyarakat Dompu yang muncul pada Masa Pra Islam yang terbagi menjadi 4 kolompok masyarakat yaitu: Ruma, Rato, Dari, dan Ada (Saleh, 1985: 7). Konsep penguburan seperti ini juga dipakai pada sistem penguburan di Situs So Langgodu dimana tutup kubur berbentuk seperti gong diperuntukkan untuk tokoh penting dan bangsawan (Kusumawati dkk, 2013: 30). Batu Dimpa sebagai penanda kubur tidak hanya berkaitan dengan aspek religi yang berhubungan dengan pemujaan leluhur sebagai akar dari budaya megalitik, namun juga terkait fungsi dan makna lain seperti stratifikasi sosial individu yang dikubur.

Konsep penguburan yang serupa juga terjadi pada penguburan sarkofagus di Bali, dinyatakan bahwa semakin tinggi teknologi dan bahan yang dipergunakan maka status sosial semakin tinggi pula. Temuan situs kubur di Desa Manikliu dalam konteks ini dapat diasumsikan bahwa individu yang dikubur dalam nekara kemungkinan memiliki status sosial yang lebih tinggi dibandingkan individu yang dikubur dalam sarkofagus dan yang dikubur tanpa wadah (Ardika dkk, 2017: 23). Selain itu perbedaan 
ukuran sarkofagus dalam penguburan ikut mempengaruhi status sosial si mati, karena semakin besar ukuran dan kompleks bentuknya maka diperlukan tenaga undagi yang ahli dan itu memakan biaya dan energi yang lebih banyak (Soejono, 2008:177)

\section{d. Sikap Badan Rangka}

Kerangka manusia yang berhasil ditemukan dari penggalian di Situs Doro Mpana sampai sejauh ini ditemukan beberapa rangka fragmentaris berupa tengkorak, tulang dan gigi. Temuan rangka dan tulang paling banyak ditemukan di kotak S20B1 spit 8 yang menghasilkan 4 fragmen tulang yang berasosiasi dengan tengkorang (R.1), fragmen gerabah terkonsentrasi, dan fitur perapian. Kotak TIS20 spit 12 dan 13 juga ditemukan fragmen tulang berjumlah 9 fragmen tulang yang sebagiannya berasosiasi dengan cranium (R.2). Namun sejauh ini belum dapat dipastikan temuan fragmen tulang tersebut merupakan tulang manusia atau binatang, karena pada spit 8 di kotak S20B1 ditemukan fragmen tulang belikat kuda dan gigi kuda. Fokus pembahasan dalam penelitian ini yakni temuan rangka R.1 dan R.2, berikut ini diuraikan lebih lanjut mengenai sikap badan dari masingmasing rangka.

1. Rangka 1 (R1) ditemukan di Kotak S20B1 di Kuadran Barat Laut berasosiasi dengan arang, temuan fragmen gerabah terkonsentrasi, dan temuan rangka berupa cranium dengan kondisi yang sudah hancur tetapi masih terlihat deretan gigi seri serta geraham atas bawah.

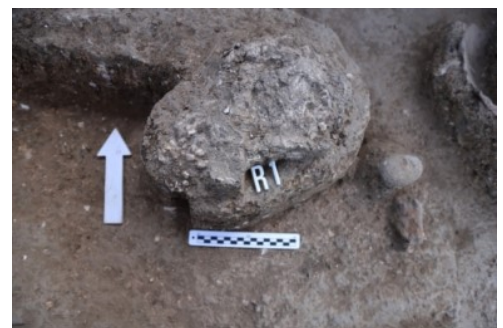

Gambar 3. Rangka R.2 di Kotak S20B1 ( Dok: Balar Bali, 2019)
2. Rangka 2 ( $\mathrm{R}$ 2) di Kotak T1S20 ditemukan bersama dengan fragmen gerabah, fragmen keramik, fragmen tulang, batu andesit, dan batu Dimpa pada Kuadran Timur Laut Spit 13 dengan kondisi yang masih bagus namun pecah mengikuti garis suturanya.

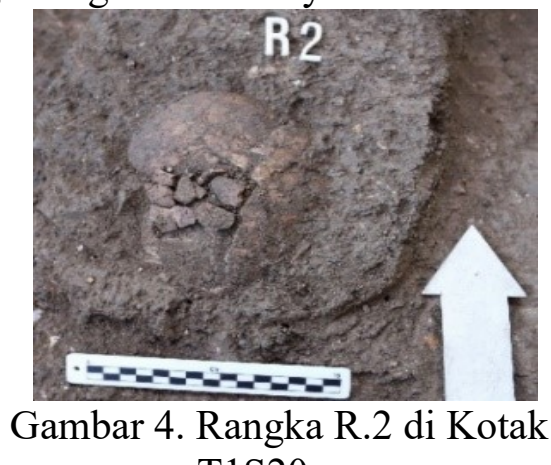

T1S20.

(Dok: Balar Bali, 2019)

Sejauh ini, belum ditemukan rangka manusia dalam bentuk yang utuh dan lengkap. Analisis hasil temuan rangka fragmentaris berupa tengkorak, tulang, dan gigi. Temuan-temuan tersebut tidak memiliki hubungan anatomi sehingga kemungkinan besar sistem penguburan yang digunakan yaitu penguburan sekunder dengan bagian tubuh berupa tengkorak saja yang diletakkan pada saat penguburan. Temuan seperti ini juga terdapat di Situs Lewoleba dan Lambanapu, dan kubur tempayan di Alor dimana ditemukan sistem penguburan sekunder yang menggunakan wadah tempayan dengan meletakkan tulang tengkorak saja di dalamnya (Hadini dkk., 2019; Hidayah, 2013).

\section{Hasil wawancara}

Wawancara dilakukan terhadap Muhamad Nur dan H. Arifin pada 24 Maret 2021. Keterangan dari kedua narasumber ini hampir serupa, dimana pada saat penggalian liar dilakukan pada 2016 ditemukan satu rangka manusia dengan posisi duduk dan posisi terlentang. Temuan ini tentu saja menarik, karena masyarakat di sekitar Situs So Langgodu juga menemukan kondisi rangka dengan posisi yang serupa sehingga diberi nama rade doho atau 
kubur duduk (Mahaviranata, 2004: 10).

Rangka yang ditemukan tersebut diduga rangka orang dewasa yang dilengkapi bekal kubur seperti gerabah, keramik dan benda logam berupa perhiasan gelang di sekitar rangka tanpa pola penempatan tertentu. Rangka dengan posisi duduk ini ditemukan berada pada kedalaman 1 meter dan di atasnya terdapat batu Dimpa. Orientasinya menghadap ke arah timur.

Selain posisi duduk, ditemukan tiga rangka manusia yang diduga sebagai rangka orang dewasa dalam satu lubang kubur yang berada di Puncak Doro Mpana. Rangka tersebut berada dalam posisi yang unik yaitu tiga rangka dengan kepala disatukan yang berorientasi badan berbeda yaitu terbujur ke arah selatan, barat, dan timur. Namun berbeda dengan kubur lain yang pernah ditemukan, rangka tersebut tidak dilengkapi dengan bekal kubur. Masyarakat percaya bahwa orang yang dikubur merupakan tokoh penting dalam masyarakat pada masa lalu, hal ini didasarkan pada lokasi kubur yang berada di Puncak Doro Mpana yang dipercaya sebagai tempat suci dan tempat bersemayamnya para roh suci leluhur.

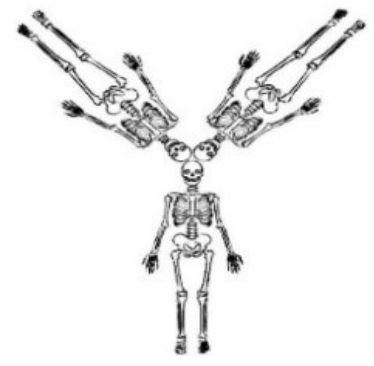

Gambar 6. Ilustrasi rangka dalam posisi terlentang di Puncak Doro Mpana

(Dok: Lila Jamilah, 2021)

Sistem penguburan ini sangat menarik karena ditemukan rangka manusia yang jumlahnya lebih dari satu individu dalam satu lubang kubur. Budaya kubur seperti ini juga terdapat pada kubur sarkofagus di Bali, kubur dolmen di Sumba, dan kubur erong di Toraja. Orang-orang yang dikubur dalam satu wadah merupakan satu keluarga atau memiliki hubungan kekerabatan (Duli, 2011a: 17). Kemungkinan rangka posisi duduk dan posisi terlentang tersebut merupakan penguburan langsung atau penguburan primer karena rangka tersebut berada dalam kondisi anatomi yang masih lengkap.

\section{e. Orientasi Arah Bujur Rangka dan Arah Hadap}

Orientasi penguburan ditentukan oleh arah bujur badan dan arah hadap wajah rangka. Penentuan arah bujur maupun arah hadap dalam pola penguburan prasejarah, erat kaitannya dengan lokasi tempat bersemayamnya roh leluhur supaya memudahkan perjalanan menuju dunia lain. Berkaitan dengan itu, terdapat empat teori yang dikemukakan oleh Binford (1972: 219), yaitu: 1) orientasi yang disusun berdasarkan analogi matahari (solar analogy) yang menganggap bahwa terletak di arah matahari terbit, 2) orientasi mayat ke tempat asal usul nenek moyang (original home of forefather) 3) orientasi menghadap ke angkasa (celestial orientation) berkaitan dengan kepercayaan bahwa arwah si mati akan menuju ke surga (angkasa) dan 4) orientasi mayat ke titik-titik utama bumi.

Berdasarkan penjelasan tersebut, maka dapat ditentukan makna dari orientasi serta arah hadap rangka di Situs Doro Mpana. Melihat posisi rangka R1 dan R2 yang diperkirakan sebagai penguburan sekunder dengan mengubur bagian tengkorak saja. Muncul dugaan lain bahwa sistem penguburan yang terjadi di Situs Doro Mpana merupakan sistem kubur primer karena sejauh ini jarang ditemukan sistem penguburan langsung tanpa wadah yang merupakan penguburan sekunder. Adapun fakta hanya ditemukannya tengkorak saja dan rangka fragmentaris lainnya kemungkinan dipengaruhi oleh faktor alam. 
Sementara hasil wawancara terkait rangka posisi duduk, kemungkinan diposisikan menghadap ke tempat asalusul nenek moyang (origin of forefather) yaitu perbukitan yang berada di sekitar Situs Doro Mpana. Posisi terlentang kemungkinan berorientasi menghadap ke angkasa (celestial orientation) berkaitan dengan kepercayaan bahwa arwah si mati dapat menuju ke surga (angkasa).

\section{f. Penyertaan Bekal Kubur}

Bekal kubur merupakan benda-benda yang dahulu merupakan kekayaan semasa hidup, dapat juga berupa peralatan untuk kegiatan ekonomi atau penyediaan makan, dan senjata (Wasita, 2002: 22). Di Situs Doro Mpana yang terlihat beberapa temuan seperti fragmen gerabah, fragmen keramik, benda logam, dan artefak batu. Namun temuan paling menonjol terlihat sebagai bekal kubur adalah gerabah dan keramik ditemukan berasosiasi dengan temuan Rangka 1 dan Rangka 2 pada kotak TIS20 dan S20B1

\section{Gerabah}

Fragmen gerabah merupakan temuan paling banyak dihasilkan selama penggalian Situs Doro Mpana, namun tidak ditemukan gerabah dalam kondisi utuh. Fragmen gerabah lokal ditemukan berupa bagian-bagian bibir, tepian, leher, badan, cucuk kendi dan pegangan yang terdiri atas gerabah berhias dan polos. Fragmen gerabah ditemukan berbagai jenis wadah dari yang halus sampai kasar.

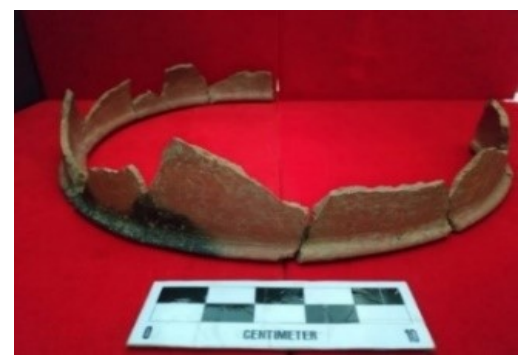

Gambar 7. Fragmen gerabah di Kotak ekskavasi S20B1. (Dok: Balar Bali, 2019)
Sebuah bentuk tepian wadah gerabah berhasil direkonstruksi (lihat gambar 7). Fragmen gerabah ini ditemukan satu konteks dengan temuan Rangka 2 dan arang yang cukup banyak. Tepian gerabah tersebut memiliki diameter 44 $\mathrm{cm}$ dan tepian terbuka sehingga dipastikan berfungsi sebagai bekal kubur.

\section{Keramik Asing}

Keramik dapat digunakan sebagai peralatan sehari-hari, perlengkapan upacara keagamaan, untuk mengungkap segi kehidupan sosial, perdagangan, politik serta ekonomi antarnegara pada masa lalu. Keramik asing yang ditemukan di Indonesia berasal dari Vietnam, Thailand, Myanmar (Burma), Khmer, dan Cina lewat hubungan politik dan perdagangan.Terkait jalur perdagangan, Dompu memiliki jalur perdagangan utama di bagian selatan yaitu Teluk Cempi. Hubungan-hubungan dagang dengan orang Tiongkok yang membawa barang-barang seperti keramik dan porselin yang ditukar dengan hasil pertanian.

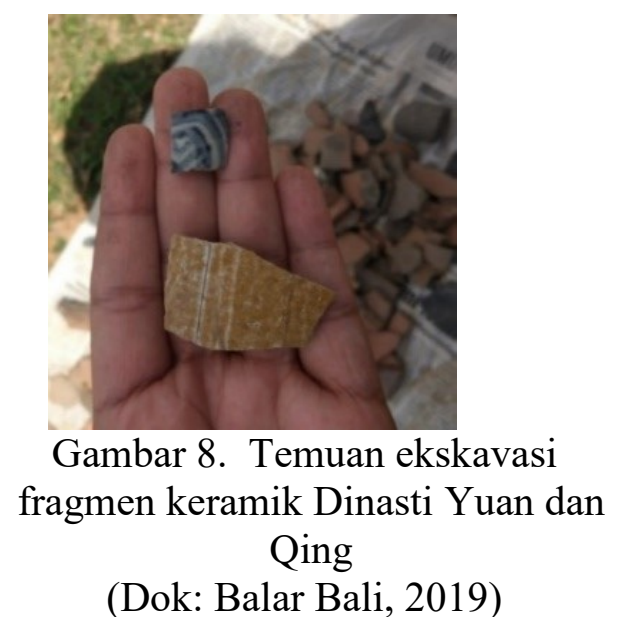

(Dok: Balar Bali, 2019)

Temuan keramik di Situs Doro Mpana menunjukkan rentang waktu yang sangat panjang, yaitu Dinasti Song (Abad ke-10-12 Masehi), Dinasti Yuan (Abad ke-13-14 Masehi), Dinasti Ming (Abad ke-14-16 Masehi) dan Dinasti Qing (Abad ke-17-19 Masehi). Keramik asing di Situs Doro Mpana belum ada yang ditemukan dalam keadaan utuh (Juliawati 
dkk., 2021: 8). Meskipun demikian, keramik di Situs Doro Mpana ditemukan menyebar pada setiap stratigrafi dan ditemukan berasosiasi dengan temuan Rangka 1 dan Rangka 2 sehingga dapat diasumsikan selain sebagai bekal kubur keramik di Situs Doro Mpana juga digunakan sebagai barang kebutuhan sehari-hari. Keramik asing juga ditemukan di situs kubur lain di Dompu seperti Situs Doro Manto ditemukan keramik Dinasti Yuan sampai Ming pada Abad ke-13 sampai 14 Masehi (Bagus, 2014: 92). Temuan ekskavasi di Situs Ta'a berupa rangka manusia dengan bekal kubur berupa keramik asing dalam bentuk utuh dari Dinasti Song dan Yuan Abad ke-10 hingga ke-14 Masehi (Ambarawati, 2003: 103).

\section{Benda Logam Perunggu}

Sejumlah benda berbahan perunggu ditemukan oleh warga di area Bukit Doro Mpana pada saat proses penggalian liar dan percarian harta karun pada 2016 yang dipercaya merupakan peninggalan kerajaan Dompu.

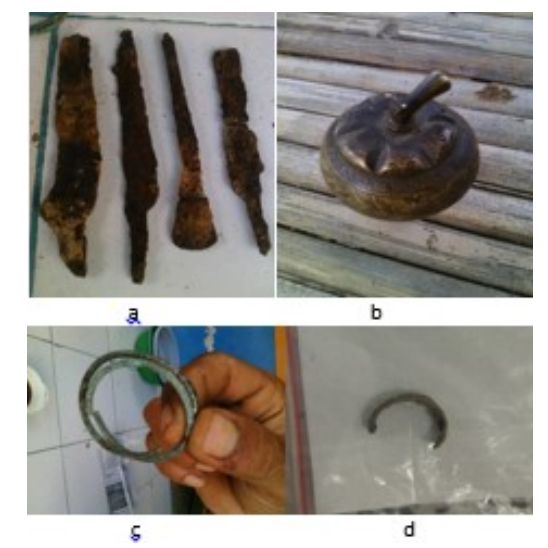

Gambar 9. Temuan Bekal kubur berbahan perunggu

(Dok: M. Nur 2016 dan Balar Bali 2019)

Temuan tersebut terdiri atas keris, gelar perunggu, dan wadah berbentuk seperti buah manggis. Benda tersebut ditemukan pada kedalaman 1 meter dari permukaan tanah bersamaan dengan temuan kerangka manusia dalam jumlah yang banyak namun sudah hancur yang diduga sebagai penguburan sekunder. Gelang perunggu juga ditemukan dalam proses ekskavasi Balar Bali di Kotak TIS20 kedalaman $135 \mathrm{~cm}$ pada 2019 yang diduga sebagai bekal kubur.

Dilihat dari ragam temuan dengan bahan yang bervariasi semakin memperkuat dugaan bahwa kontak dengan komunitas yang membawa benda-benda tersebut ke wilayah Dompu sebagai barang pertukaran atau perdagangan. Dugaan itu juga didukung dengan Dompu yang memeiliki suatu teluk yang cukup strategis sebagai pelabuhan transit yaitu Teluk Cempi. Kondisi ini yang menjadi salah satu pendukung terjalinnya komunikasi masyarakat Dompu dengan komunitas yang datang dari luar. Selain adanya jalur perdagangan dan pelayaran, analisis temuan artefak yang berupa bekal kubur juga menunjukkan adanya kontak masyarakat di Situs Doro Mpana dengan komunitas luar. Bekal kubur yang diduga dipasok dari luar berupa keramik, gerabah, dan logam perunggu. Bendabenda tersebut memiliki bahan dan teknik pengerjaan yang cukup rumit dan diduga merupakan komoditas dari luar Dompu. Beberapa penjelasan di atas, jelas bahwa masyarakat Situs Doro Mpana memang melakukan kontak dengan pihak luar dengan melakukan kegiatan pertukaran barang. Hal ini diperkuat dengan tidak ditemukannya "bengkel" atau tempat pembuatan benda-benda yang menjadi bekal kubur. Benda-benda dengan bahan dan teknik pengerjaan yang cukup rumit mungkin belum bisa diterapkan pada masyarakat Situs Doro Mpana pada saat itu karena terbatasnya sumber bahan dan pengetahuan.

\section{g. Kronologi Situs Doro Mpana}

Situs Doro Mpana mempunyai fungsi permukiman dan juga penguburan. Hal yang perlu diteliti lebih lanjut adalah kronologi absolut pemanfaatan situs, baik sebagai permukiman maupun 
penguburan. Maka dilakukan analisis C14 dengan mengumpulkan beberapa sampel arang dari kotak ekskavasi yaitu dari Kotak S20B1 spit 5, 7 dan 8; Kotak T1S20 spit 11, 12 dan 13; Kotak S26B6 spit 3.

Tabel 1.

\begin{tabular}{|c|c|c|}
\hline Kode sampel & $\begin{array}{l}\text { Kode } \\
\text { sampel } \\
\text { Lab. }\end{array}$ & Hasil \\
\hline DMP/II/2019/Chr 5 & Wk- 50162 & $599 \pm 21 \mathrm{CalBP}$ \\
\hline DMP/II/2019/Chr 7 BL & Wk- 50161 & $673 \pm 21 \mathrm{CalBP}$ \\
\hline DMP/II/2019/Chr 8 & Wk- 50159 & $620 \pm 21 \mathrm{CalBP}$ \\
\hline DMP/II/2019/T1S20/Chr11 & Wk- 50160 & $614 \pm 20$ CalBP \\
\hline DMP/II/2019/T1S20/Chr12 & Wk- 50156 & $609 \pm 21 \mathrm{CalBP}$ \\
\hline DMP/II/2019/T1S20/Chr13 & Wk- 50157 & $685 \pm 21 \mathrm{CalBP}$ \\
\hline DMP/II/2019/S26B6/Chr3 & Wk- 50158 & $447 \pm 21 \mathrm{CalBP}$ \\
\hline
\end{tabular}

Kode Wk-50161 berasal dari arang yang cukup banyak di Kotak S20B1 spit 7 berasosiasi dengan temuan fragmen gerabah dan Rangka 1 (R.1), sehingga dapat disimpulkan Rangka 1 berasal dari $673 \pm 21$ CalBP atau sekitar 1325-1367 Masehi. Sementara itu, bagian cranium Rangka 2 (R.2) ditemukan di Kotak T1S20 di akhir spit 13. Temuan rangka ini berasosiasi dengan temuan arang yang kemudian dijadikan sampel dalam analisis carbondating dengan kode Wk50157 yang menghasilkan kronologi 685 \pm 21 CalBP atau sekitar 1313-1355 Masehi.

Jika dikaitkan dengan perjalanan sejarah Dompu, maka Situs Doro Mpana dimanfaatkan pada saat Dompu belum mendapat pengaruh Hindu-Budha ataupun Islam. Peristiwa ekspansi Majapahit ke Dompu menjadi tolok ukur untuk mengetahui pemanfaatan Situs Doro Mpana sebagai penguburan yang terjadi pada masa peralihan dari Masa Ncuhi hingga awal masuknya pengaruh Majapahit. Di dalam Sumpah Palapa disebutkan daerah Dompu sebagai salah satu wilayah yang harus ditundukkan oleh Patih Gajah Mada, maka diperkirakan telah terjadi peperangan besar antara prajurit Majapahit dengan prajurit Kerajaan Dompu dua kali berturut-turut yaitu pada tahun 1340 Masehi dan 1357 Masehi (Saleh, 1985: 40).

\section{SIMPULAN}

Aktivitas penguburan yang dilakukan masyarakat pendukung Doro Mpana sangat menarik karena memanfaatkan batu Dimpa sebagai penanda kubur. Batu Dimpa dikategorikan menjadi empat berdasarkan bentuknya yaitu tipe monolith, tipe bulat alami, tipe trapesium, dan tipe segi empat. Ukurannya terbagi menjadi tiga yaitu kecil, sedang, dan besar. Perbedaan bentuk dan ukuran pada batu Dimpa ini kemungkinan dipengaruhi oleh status sosial si mati. Hal ini bukan tanpa alasan, melihat tingkat kesulitan untuk memperoleh bahan batu Dimpa dan proses pengerjaan yang membutuhkan waktu dan biaya yang jauh lebih besar.

Penguburan yang diterapkan oleh masyarakat Doro Mpana pada masa lalu adalah penguburan sekunder dan penguburan primer dengan posisi duduk dan posisi terlentang. Penempatan mayat dalam proses penguburan di Doro Mpana ditemukan dalam sikap terlipat atau duduk dan sikap terlentang. Sikap terlipat telah ada sejak Masa Paleolitik. Posisi duduk atau terlipat yang berkaitan dengan ke tempat asal-usul nenek moyang (origin of forefather) yaitu perbukitan yang berada di sekitar Situs Doro Mpana. Posisi terlentang di bagian kepala memusat pada satu titik tengah dengan posisi wajah menghadap ke atas (celestial orientation) berkaitan dengan kepercayaan bahwa arwah si mati menuju ke surga. Temuan seperti fragmen gerabah dan fragmen keramik yang paling menonjol terlihat sebagai bekal kubur yang ditemukan berasosiasi dengan temuan Rangka 1 dan Rangka 2 pada kotak TIS20 dan S20B1. Selain itu 
terdapat temuan berupa benda berbahan logam perunggu diduga kuat sebagai bekal kubur.

Penguburan yang berlangsung di Situs Doro Mpana secara konsep berkaitan erat dengan kepercayaan masyarakat Prasejarah. Hal ini terlihat pada tata cara penanganan orang mati seperti posisi dan sikap rangka, orientasi, penggunaan batu Dimpa, dan penyertaan bekal kubur. Hal ini terjadi tidak lepas dari konsep kepercayaan yang dianut oleh masyarakat pendukung situs Doro Mpana pada masa Prasejarah yang memuja roh dan kekuatann leluhur atau parafu.

Adanya hasil penelitian ini, maka penulis menyarankan untuk mengadakan penelitian lanjutan secara luas dan lebih mendalam. Seperti penelitian tentang osteologi terhadap rangka-rangka temuan di Situs Doro Mpana untuk menentukan umur, ras, jenis kelamin, penyebab kematian, dan kebiasaan hidup.

Situs Doro Mpana sangat penting dan seharusnya mendapatkan perhatian khusus karena mengacu pada kurangnya pengertian terhadap arti pentingnya suatu peninggalan sejarah. Besar harapan penulis dengan berbagai informasi yang disajikan dalam skripsi ini dapat dijadikan sebagai bahan pertimbangan pemerintah dan pemerhati Cagar Budaya dalam menjaga kelestarian Situs Doro Mpana dari kegiatan penggalian liar dan pengrusakan yang masih banyak terjadi di Dompu. Penulis sangat mengharapkan supaya hal-hal semacam ini tidak terjadi lagi situs-situs arkeologi lainnya. Semoga apa yang penulis sampaikan mendapat perhatian dari semua pihak yang berkompeten.

\section{DAFTAR PUSTAKA}

Ambarawati, Ayu. (2003). "Keramik Dari Situs Kubur Ta'a, Kecamatan Kempo, Kabupaten Dompu." Forum Arkeologi 16 (2): 98-106.
Denpasar: Balai Arkeologi Denpasar.

Ardika, I. W., Setiawan, I. K., Srijaya, I. W., \& Bawono, R. A. (2017). Stratifikasi sosial pada masa prasejarah di Bali. Udayana University Press.

Bagus, A.A. Gde. (2014). "Keramik Situs So Langgodu, Dompu: Indikasi Permukiman Masa Lalu". Jurnal Forum Arkeologi. Volume 27. Nomor 2. Hal 89 - 98. Balai Arkeologi Denpasar.

Binford. Lewis R. (1972). An Archaeological Perspective. SeminarPress. New York/London.

Duli, Akin. (2011). "Keranda Erong Dalam Sistem Penguburan Akhir Jaman Prasejarah di Sulawesi Selatan". Jurnal Lensa Budaya. Vol 6. No.2. Edisi Agos 2011.

Handini, Retno. dkk (2019). "Situs Lambanapu: Diaspora Austronesia di Sumba Timur". Jurnal Amerta. Jakarta: Pusat Penelitian Arkeologi Nasional.

Heekeren, H.R.van. (1972). The Stone Age of Indonesia. Second Edition. The Hague: Martinus Nijhoff.

Hidayah, Ati Rati. (2013). "Kubur Tempayan di Kabupaten Alor Nusa Tenggara Timur". Jurnal Forum Arkeologi. Vol. 2. No. 2. Hal 135144. Balai Arkeologi Denpasar.

Juliawati, Ni Putu Eka. dkk (2018). "Ekskavasi Situs Doro Mpana: Menelusuri Jejak Pemukiman Masa Awal Kesultanan Dompu". Laporan Penelitian Arkeologi. Denpasar: Balai Arkeologi Denpasar. 
Juliawati, Ni Putu Eka. dkk (2021). "DORO MPANA: Situs Kubur Dari Abad Ke-13-14 Masehi”. Jurnal Forum Arkeologi. Denpasar: Balai Arkeologi Denpasar.

Juliawati, Ni Putu Eka. dkk (2019). "Ekskavasi Situs Doro Mpana: Menelusuri Jejak Pemukiman Masa Awal Kesultanan Dompu Tahap II". Laporan Penelitian Arkeologi. Denpasar: Balai Arkeologi Denpasar.

Koentjaraningrat. (1985). Pengantar Ilmu Antropologi. Jakarta: Aksara Baru.

Kusumawati, Ayu. dkk (2013). "Ekskavasi dan Survei di Kecamatan Hu'u, Kabupaten Dompu". Laporan Penelitian Arkeologi, No. 02. Denpasar: Balai Arkeologi Denpasar.

Mahaviranata, Purusa. (2004). "Budaya Kubur Prasejarah Di Desa Hu'u, Dompu, NTB". Forum Arkeologi.No.1. Hal 1-14. Balai Arkeologi Denpasar.

Prasetyo, Bagyo. dkk (2004). Religi pada Masyarakat Prasejarah di Indonesia. Jakarta: Kementerian Kebudayaan dan Pariwisata, Proyek Penelitian dan Pengembangan Arkeologi.

Saleh, Israil M. (1985). Sekitar Kerajaan Dompu, Pemerintah Daerah Tingkat II Dompu, Dompu.

Soejono, R. P. (2008). Sistem-Sistem Penguburan pada Akhir Masa Prasejarah di Bali. Jakarta. Pusat Penelitian Dan Pengembangan Arkeologi Nasional.

Soejono, R.P. (1984). Sejarah Nasional Indonesia I. Jakarta: Balai Pustaka.
Soejono, R.P. D.D. dkk (1993). Zaman Prasejarah di Indonesia, Sejarah Nasional Indonesia I, ed. Ke-4 (Eds. Marwati Djoned Pusponegoro, Nugroho Notosusanto), Departemen Pendidikan dan Kebudayaan, Balai Pustaka.

Soekanto, Soerjono. (2012). Sosiologi Suatu Pengantar. Jakarta: Rajawali Pers.

Taufikurrahman. (2018). "Islamisasi Kerajaan Dompu Masa Sultan Syamsuddin 1635-1659 M". Skripsi. Makassar: Fakultas Adab dan Humaniora UIN Alauddin.

Wasita. (2002). "Sistem Penguburan dan Upacara Marabia pada Masyarakat Paju Sepuluh Di Kabupaten Barito Selatan, Kalimantan Tengah." Berita Penelitian Arkeologi. Banjarmasin: Balai Arkeologi Deputi Bidang Pelestarian dan Pengembangan Budaya Badan Pengembangan Budaya dan Pariwisata.

Widianto, Harry. Agus Soedjono. D. Suryanto. (1990). "Sistem Penguburan Masyarakat Megalitik: Kajian Atas Data Hasil Ekskavasi Kubur Kalang di Bojonegoro dan Tuban," dalam Analisis Hasil Penelitian Arkeologi I di Plawangan.Jakarta: Pusat Penelitian Arkeologi Nasional. 